\title{
Isolation of cytotoxic triterpenes from the mangrove plant, Scyphiphora hydrophyllacea C.F.Gaertn (Rubiaceae)
}

\author{
Sameera R Samarakoon ${ }^{1 *}$, Meran K Ediriweera', Lakshan Wijayabandara', \\ Nisala Fernando ${ }^{1}$, Luxmiga Tharmarajah ${ }^{1}$, Kamani H Tennekoon ${ }^{1}$, Poorna \\ Piyathilaka1, Achyut Adhikari ${ }^{2,3}$ \\ ${ }^{1}$ Institute of Biochemistry, Molecular Biology and Biotechnology, No. 90, Cumaratunga Munidasa Mawatha, Colombo 03, Sri \\ Lanka, ${ }^{2}$ Central Department of Chemistry, Tribhuvan University, Kritipur, Kathmandu, Nepal, ${ }^{3} \mathrm{HEJ}$ Research Institute of \\ Chemistry, International Center for Chemical and Biological Sciences, University of Karachi, Karachi, Pakistan
}

*For correspondence: Email: sam@ibmbb.cmb.ac.lk; Tel: +94-772988414

\begin{abstract}
Purpose: To isolate active cytotoxic compounds from the hexane and chloroform extracts of the leaves of the mangrove plant, Scyphiphora hydrophyllacea C.F. Gaertn (Rubiaceae), grown in Sri Lanka. Methods: Dried pulverized leaves of S. hydrophyllacea were extracted with hexane and chloroform. Vacuum liquid chromatography (VLC), column chromatography (size exclusion chromatography, Sephadex $\mathrm{LH}-20$ ) and reversed phase preparative recycling high performance liquid chromatography (HPLC) techniques were used to isolate three compounds (compounds 1, 2 and 3). The structures of the isolated compounds were established with the aid of ${ }^{1} \mathrm{H},{ }^{13} \mathrm{C}$ and two-dimensional nuclear magnetic resonance (2D-NMR) and electron ionization-mass spectrometry (EI-MS) techniques. 3-(4,5Dimethylthiazol-2-yl)-2,5-diphenyltetrazolium bromide (MTT) assay was used to evaluate the cytotoxic effects of the compounds on oestrogen receptor positive breast (MCF-7) and non-small cell lung (NCI$H$-292) cancer cells.

Results: The isolated compounds were identified as oleanolic acid (1), ursolic acid (2) and eichlerianic acid (3). Ursolic acid and eichlerianic acid showed strong cytotoxic effects \{IC 50- $^{-}$ursolic acid: 8.47 $\mu \mathrm{g} / \mathrm{mL}$ (24 h, MCF-7), $7.78 \mu \mathrm{g} / \mathrm{mL}$ (24 $\mathrm{h}$, NCl-H292) and eichlerianic acid: $8.86 \mu \mathrm{g} / \mathrm{mL}$ (24 $\mathrm{h}, \mathrm{MCF}-7$ ), $10.15 \mu \mathrm{g} / \mathrm{mL}(24 \mathrm{~h}, \mathrm{NCl}-\mathrm{H} 292)\}$ in MCF-7 and NCl-H292 cancer cells at 24, 48 and $72 \mathrm{~h}$ post-incubation periods.

Conclusion: Hexane and chloroform extracts of the leaves of S. hydrophyllacea yielded three compounds namely oleanolic acid, eichlerianic acid and ursolic acid. Ursolic acid and eichlerianic acid have been isolated for the first time from the leaves of S. hydrophyllacea grown in Sri Lanka and demonstrate in-vitro cytotoxic effects in oestrogen receptor positive (MCF-7) and non-small lung cancer (NCl-H-292) cells.
\end{abstract}

Keywords: Scyphiphora hydrophyllacea, eichlerianic acid, ursolic acid, oleanolic acid, MCF-7, NCl-H292

This is an Open Access article that uses a funding model which does not charge readers or their institutions for access and distributed under the terms of the Creative Commons Attribution License (http://creativecommons.org/licenses/by/4.0) and the Budapest Open Access Initiative (http://www.budapestopenaccessinitiative.org/read), which permit unrestricted use, distribution, and reproduction in any medium, provided the original work is properly credited.

Tropical Journal of Pharmaceutical Research is indexed by Science Citation Index (SciSearch), Scopus, International Pharmaceutical Abstract, Chemical Abstracts, Embase, Index Copernicus, EBSCO, African Index Medicus, JournalSeek, Journal Citation Reports/Science Edition, Directory of Open Access Journals (DOAJ), African Journal Online, Bioline International, Open-J-Gate and Pharmacy Abstracts 


\section{INTRODUCTION}

Cancer is considered a major cause of death in the world [1]. Lung and breast cancers are the most commonly diagnosed cancer among men and women respectively. Despite the availability of modern cancer treatment options, there is no permanent cure for cancer [2,3]. Radiotherapy, chemotherapy, hormone therapy and surgery are the main available treatment options for cancer $[4,5]$. Chemotherapy and radiotherapy will be the ultimate treatment option for metastatic cancer when surgery causes some functional defects in the organs and systems of the patient. However, chemotherapy and radiotherapy cause severe side effects [6]. Therefore identification of alternative treatment options for cancer with fewer side effects is of paramount importance. Phytochemicals have gained much attention in the development of cancer drugs and several plant derived natural compounds have been developed as anti-cancer drugs [7].

Mangroves are considered as one of the main productive coastal eco-systems. Mangroves have widely been used in traditional medicine to treat cancers and a number of natural compounds with different bio-activities have been reported from several mangrove plants [8]. $S$. hydrophyllacea (Family: Rubiaceae) is one of the common mangrove plants found mainly in South Asia including Sri Lanka [8, 9]. Several flavonoids, terpenoids and iridoids have been isolated from $S$. hydrophyllacea by previous researchers [9]. Cytotoxic and apoptotic properties of leaf and bark extracts of $S$. hydrophyllacea and isolation of hopenone-I from the hexane leaf extract of $S$. hydrophyllacea have reported in our previous studies [10,11]. The present study was aimed at to isolate cytotoxic compound/s in the active hexane and chloroform extracts of $S$. hydrophyllacea leaves and to evaluate their cytotoxic effects in nonsmall cell lung ( $\mathrm{NCl}-\mathrm{H} 292)$ and breast cancer (MCF-7) cells.

\section{EXPERIMENTAL}

\section{General}

Cell lines and cell culture reagentsused in this studuy were purchased from the ATCC (American Type Culture Collection , Manassas, USA) and all the chemicals in the study were purchased from the Sigma-Aldrich (St Louis, MO, USA) unless otherwise stated. Bruker AV500 and AV-600 NMR instruments (Fällanden, Switzerland) were used to record NMR spectra. Synergy $^{\mathrm{TM}}$ HT Multi-Mode micro plate reader (Bio- Tek, Winooski, VT) was used to measure absorbance. All the solvents used in this study were of analytical grade.

\section{Collection of plant material}

Leaves of S. hydrophyllacea were collected from the same plant used for our previous studies [10, 11]. Leaves of the plant were collected from the National Aquatic Resources Research and Development Agency (NARA) Negombo, Sri Lanka and the plant material was identified by Mr. W.A. Sumanadasa, Research Officer at NARA. Voucher specimen (no. S-11) of the plant was deposited at the herbarium of IBMBB, University of Colombo, Sri Lanka.

\section{Extraction and isolation of compounds}

Air-dried pulverized leaves of $S$. hydrophyllacea $(1.5 \mathrm{~kg})$ were extracted with hexane $(3 \times 1.75 \mathrm{~L})$ and chloroform $(3 \times 1.75 \mathrm{~L})$ by sonication at room temperature. Resulting chloroform extract was concentrated (32 g) and subjected to vacuum liquid chromatography (VLC) with a gradient solvent system composed of hexane: ethyl acetate (100:0 to $0: 100)$ to yield 10 fractions. Fraction $9(7.6 \mathrm{~g})$, which was found to be cytotoxic, was seperated in a Sephadex LH20 column $(120 \times 3.5 \mathrm{~cm})$ with $50 \%(\mathrm{v} / \mathrm{v})$ dichloromethane and methanol to yield 17 fractions. The collected fractions were combined according to TLC profiles to make 4 fractions which were then subjected for cytotoxic evaluations. Most active fraction (fraction 3, 30 $\mathrm{mg}$ ) was then subjected to preparative recycling HPLC in a normal-phase column with isocratic elution $\left[5 \%(\mathrm{v} / \mathrm{v}) \mathrm{MeOH}\right.$ in $\mathrm{CHCl}_{3}$; flow rate: 5 $\mathrm{mL} / \mathrm{min}]$. Peaks were detected using refractive index detector (RI detector) at a sensitivity of $20 \mathrm{~nm} / \mathrm{RIU}$. Two recycled base line separated peaks were collected to afford compounds 1 (7 $\mathrm{mg}$ ) and 2 (12 mg).

Hexane crude extract (12 g) was subjected to vacuum liquid chromatography (VLC) with hexane : ethyl acetate (100:0 to 0:100) to yield 10 fractions. Fraction 6, which showed the most cytotoxic activity, was chromatographed on a normal phase silica column with hexane: ethyl acetate (100:0-0:100) to yield 20 fractions. As the fraction 14 (200 mg) exerted most cytotoxic effects it was separated in a Sephadex LH-20 column $(120 \times 3.5 \mathrm{~cm})$ with $50 \%$ (v/v) dichloromethane and methanol to yield compound 3 (120 mg).

\section{Structure elucidation}

Structures of the isolated compounds were established through of UV and IR spectroscopy, 

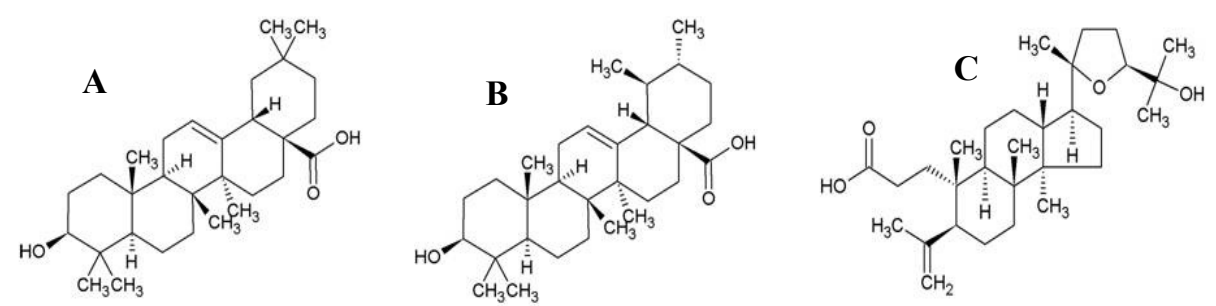

Figure 1: Structures of isolated compounds 1-3

${ }^{1} \mathrm{H}-\mathrm{NMR},{ }^{13} \mathrm{C}-\mathrm{NMR}, 2 \mathrm{D}-\mathrm{NMR}$ (COSY, HSQC, and $\mathrm{HMBC}$ ) and ESI-MS techniques.

\section{Cell culture}

Oestrogen receptor positive breast cancer (MCF7 ) and non-small cell lung (NCl-H292) cancer cells were plated in 96-well cell culture plates in Dulbecco's Modified Eagle's Medium (DMEM) at $37{ }^{\circ} \mathrm{C}$ in $95 \%$ air and $5 \% \mathrm{CO}_{2}$ atmosphere with $95 \%$ humidity.

\section{Cytotoxic assay}

MTT assay was carried out as previously described methods [12,13]. Cancer cells plated in 96 well plates were treated with different concentrations $(6.25,12.5,25,50$ and 100 $\mu \mathrm{g} / \mathrm{mL}$ ) of compounds and incubated for 24, 48 and $72 \mathrm{~h}$. After incubation, MTT reagent $(20 \mu \mathrm{L}$ of $1 \mathrm{mg} / \mathrm{mLstock}$ solution) was added to each well and plates were incubated for $4 \mathrm{~h}$ at $37^{\circ} \mathrm{C}$. Following incubation, content was removed from each well and $100 \mu \mathrm{L}$ of isopropanol $/ \mathrm{HCl}$ mixture was added. Absorbance of treated and untreated wells were measured at $570 \mathrm{~nm}$ in a micro plate reader. Paclitaxel was used as the positive control.

\section{Morphological examination}

Morphological changes of breast (MCF-7) and lung cancer ( $\mathrm{NCl}-\mathrm{H} 292)$ cells exposed to three compounds were examined under phase contrast microscope (OPTIKA, XDS 3, Italy).

\section{Statistical analysis}

Data are shown as mean \pm SD $(n=3)$. Statistical differences as well as half-maximal inhibitory concentration $\left(\mathrm{IC}_{50}\right)$ values of the three compounds in two different cancer cells were analyzed using GraphPad Prism 5 (San Diego, California, USA) software package. $P<0.05$ was taken as statistically significant.

\section{RESULTS}

\section{Structure of isolated compounds}

Structure of compound 1 and 2 were confirmed as oleanolic acid and ursolic acid by comparing NMR and mass spectroscopic data of these two compounds with reported data (Table 1 and 2) in literature [14,15]. Compound 3 was obtained as a white powder. El-MS spectrum of compound 3 displayed pseudo molecular ion peaks at $\mathrm{m} / \mathrm{z}$ $475\left[\mathrm{M}^{+}+\mathrm{H}\right]$ and $492\left[\mathrm{M}^{+}+\mathrm{NH}_{4}\right]$. El-MS spectrum displayed peaks at $m / z 459\left(\mathrm{M}^{+}-\mathrm{Me}\right)$, $441\left(\left(\mathrm{M}^{+}-\mathrm{Me}-\mathrm{H}_{2} \mathrm{O}\right), 415\left(\mathrm{M}^{+}-\mathrm{Me}-\mathrm{COOH}\right), 397\right.$, 143 and $125 .{ }^{1} \mathrm{H}$ - and ${ }^{13} \mathrm{C}-\mathrm{NMR}$ chemical shift values of compound 3 found to be similar with reported compound eichlerianic acid [14].

Comparative NMR chemical shift values of compound 3 are given in Table 3 . Structure of compound 3 was further confirmed from 2D-NMR spectroscopic techniques (HSQC, COSY, HMBC and NOESY). Structures of the isolated compounds are shown in Figure 1.

\section{Cytotoxic effects of isolated compounds}

Cytotoxic effects of isolated compounds are shown in the Table 4. All three compounds were cytotoxic to cell lines tested. Compared to compound 1 (oleanolic acid), compound 2 (ursolic acid) and compound $\mathbf{3}$ (eichlerianic acid) were highly cytotoxic to both cancer cell lines tested. However compound $\mathbf{3}$ appeared to exert a higher effect in breast cancer cells than in lung cancer cells.

Table 4: $\mathrm{IC}_{50}$ values (in $\mu \mathrm{g} / \mathrm{mL}$ ) of oleanolic acid (compound 1), ursolic acid (compound 2) and eichlerianic acid (compound 3 ) in MCF-7 and $\mathrm{NCl}$ $\mathrm{H} 292$ cells at 24,48 and $72 \mathrm{~h}$ incubation periods

\begin{tabular}{lcccccc}
\hline Compound & \multicolumn{3}{c}{ MCF-7 } & \multicolumn{3}{c}{ NCI -H292 } \\
\cline { 2 - 7 } & $\mathbf{2 4} h$ & $\mathbf{4 8} h$ & $\mathbf{7 2} h$ & $\mathbf{2 4} h$ & $\mathbf{4 8} h$ & $\mathbf{7 2} h$ \\
\hline $\mathbf{1}$ & 208.4 & 141.6 & 118.9 & 102.5 & 80.96 & 62.84 \\
$\mathbf{2}$ & 8.47 & 7.06 & 4.36 & 7.78 & 6.26 & 5.72 \\
$\mathbf{3}$ & 8.86 & 7.22 & 5.00 & 10.15 & 9.77 & 8.35 \\
Paclitaxel & 4.25 & 3.18 & 1.94 & 10.2 & 3.25 & 1.25 \\
\hline
\end{tabular}

\section{Morphological observations}

Changes in cell structure such as membrane blebbing and apoptotic body formation changers in cell shape and decrease in cell number were evident in lung and breast cancer cells after 
Table 1: ${ }^{13} \mathrm{C}$ NMR $(150 \mathrm{MHz})$ and ${ }^{1} \mathrm{H}$ NMR data $(600 \mathrm{MHz})$ of oleanolic acid (1) $\left(\mathrm{CDCl}_{3}\right)$

\begin{tabular}{|c|c|c|c|c|}
\hline \multirow[t]{2}{*}{ Position } & \multicolumn{2}{|c|}{ Reported data [15] } & \multicolumn{2}{|c|}{ Observed data } \\
\hline & $\delta C$ & $\delta H(J H z)$ & $\delta C$ & $\delta H(J H z)$ \\
\hline 1 & 38.5 & $1.63(\mathrm{~m})$ & 38.5 & $1.63(\mathrm{~m})$ \\
\hline 2 & 28.1 & $1.60(\mathrm{~m})$ & 28.1 & $1.59(\mathrm{~m})$ \\
\hline 3 & 79.1 & $\begin{array}{c}3.23(\mathrm{dd} ; J=10.7 \\
4.7 \mathrm{~Hz}\end{array}$ & 79.1 & $\begin{array}{c}3.20(\mathrm{dd} ; J=4.5 ; \\
10.0 \mathrm{~Hz})\end{array}$ \\
\hline 4 & 38.8 & - & 38.8 & \\
\hline 5 & 55.3 & $0.74(\mathrm{~m}$ & 55.2 & $0.71(\mathrm{~m})$ \\
\hline 6 & 18.8 & $1.54(\mathrm{~m})$ & 18.2 & $1.54(\mathrm{~m})$ \\
\hline 7 & 32.7 & $1.49(\mathrm{~m})$ & 32.9 & $1.48(\mathrm{~m})$ \\
\hline 8 & 39.3 & - & 39.4 & \\
\hline 9 & 47.6 & $1.54(\mathrm{~m}$ & 47.5 & $1.54(\mathrm{~m})$ \\
\hline 10 & 37.0 & - & 37.0 & \\
\hline 11 & 23.8 & $0.94(\mathrm{~m})$ & 23.5 & $0.94(\mathrm{~m})$ \\
\hline 12 & 122.8 & $\begin{array}{c}5.31(\mathrm{dd} ; J=3.6 \\
3.5 \mathrm{~Hz})\end{array}$ & 125.8 & $\begin{array}{c}5.23(\mathrm{~d} ; J=22.5 \\
\mathrm{Hz})\end{array}$ \\
\hline 13 & 143.5 & - & 137.9 & \\
\hline 14 & 41.5 & - & 41.9 & \\
\hline 15 & 27.7 & $1.60(\mathrm{~m})$ & 27.9 & $1.61(\mathrm{~m})$ \\
\hline 16 & 23.7 & $0.94(\mathrm{~m})$ & 24.1 & $0.96(\mathrm{~m})$ \\
\hline 17 & 46.7 & - & 47.8 & \\
\hline 18 & 42.1 & $2.82(\mathrm{~m})$ & 41.9 & \\
\hline 19 & 46.0 & $2.87(\mathrm{~m})$ & 47.5 & \\
\hline 20 & 31.0 & - & 30.6 & \\
\hline 21 & 33.9 & $1.62(\mathrm{~m})$ & 38.75 & $1.63(\mathrm{~m})$ \\
\hline 22 & 33.2 & $1.30(\mathrm{~m})$ & 36.98 & $1.31(\mathrm{~m})$ \\
\hline 23 & 28.0 & 1.00 (s) & 28.12 & $0.96(s)$ \\
\hline 24 & 16.8 & 0.79 (s) & 16.9 & $0.75(\mathrm{~s})$ \\
\hline 25 & 15.3 & 0.93 (s) & 15.4 & 0.91 (s) \\
\hline 26 & 17.1 & 0.79 (s) & 17.0 & 0.76 (s) \\
\hline 27 & 26.0 & 1.16 (s) & 27.2 & 1.06 (s) \\
\hline 28 & 180.0 & - & 181.2 & \\
\hline 29 & 33.1 & 0.92 (s) & 36.68 & 0.84 (s) \\
\hline 30 & 23.7 & 0.94 (s) & 23.2 & 0.93 (s) \\
\hline
\end{tabular}

treatment with the three compounds at 24,48 and $72 \mathrm{~h}$ incubations (Figure 2 and Figure 3 ).

\section{DISCUSSION}

Scyphiphora hydrophyllacea is a mangrove plant of the family Rubiaceae which is widely distributed in Asia and Western Pacific [9]. Presence of flavonoids, terpinoids and iridoids in the mangrove plant $S$. Hydrophyllacea has already been reported [9]. Structures of three compounds isolated from the hexane and chloroform extracts of leaves of $S$. Hydrophyllacea were elucidated by means of ${ }^{1}$ $\mathrm{H}$ - and ${ }^{13} \mathrm{C}-\mathrm{NMR}$ data and the compounds were identified as oleanolic acid (compound 1), ursolic acid (compound 2) and eichlerianic acid (compound 3). Although isolation and structure elucidation of ursolic acid and oleanolic acid from several other mangrove varieties has been reported $[16,17]$, this is the first report on the isolation eichlerianic acid from S. Hydrophyllacea leaves.

Cytotoxicity results from the cytotoxic assays demonstrated that, among the three compounds ursolic acid and eichlerianic acid exerted strong cytotoxic effects on non-small lung cancer cells $(\mathrm{NCl}-\mathrm{H} 292)$ and oestrogen receptor positive (MCF-7) breast cancer cells at 24, 48 and $72 \mathrm{~h}$ post incubation periods. Morphological changes (changes in cell shape, volume and decrease in cell number) observed in ursolic acid and eichlerianic acid-treated cancer cells also confirmed cancer cell growth inhibitory effects of these two compounds. Oleanolic acid showed less cytotoxic effects in both the cancer cell lines tested.

Several researchers have also evaluated the cytotoxic effects of ursolic acid and eichlerianic acid [18-21] isolated from other plant species in several cancer cell lines including MCF-7 breast cancer cells [22,23] and those results are some 
Table 2: ${ }^{13} \mathrm{C}$ NMR $(150 \mathrm{MHz})$ and ${ }^{1} \mathrm{H}$ NMR data $(600 \mathrm{MHz})$ of ursolic acid (2) $\left(\mathrm{CDCl}_{3}\right)$

\begin{tabular}{|c|c|c|c|c|}
\hline \multirow[t]{2}{*}{ Position } & \multicolumn{2}{|c|}{ Reported data [15] } & \multicolumn{2}{|c|}{ Observed data } \\
\hline & $\delta C$ & $\delta H(J H z)$ & $\delta C$ & $\delta H(J H z)$ \\
\hline 1 & 38.6 & $1.72(\mathrm{~m})$ & 38.8 & $1.74(\mathrm{~m})$ \\
\hline 2 & 28.2 & $1.60(\mathrm{~m})$ & 28.0 & $1.60(\mathrm{~m})$ \\
\hline 3 & 78.7 & $3.22(\mathrm{dd} ; J=10.8 ; 4.9 \mathrm{~Hz})$ & 78.9 & $3.16(\mathrm{dd} ; J=4.5,9.0 \mathrm{~Hz})$ \\
\hline 4 & 38.5 & & 38.5 & \\
\hline 5 & 55.2 & $1.34(\mathrm{~m})$ & 55.1 & \\
\hline 6 & 18.3 & $1.60(\mathrm{~m})$ & 18.2 & $1.60(\mathrm{~m})$ \\
\hline 7 & 32.9 & $1.72(\mathrm{~m})$ & 32.9 & $1.74(\mathrm{~m})$ \\
\hline 8 & 39.5 & & 39.0 & \\
\hline 9 & 47.3 & $1.60(\mathrm{~m})$ & 47.4 & $1.60(\mathrm{~m})$ \\
\hline 10 & 37.0 & & 36.7 & \\
\hline 11 & 23.7 & $1.91(\mathrm{~m})$ & 23.4 & $1.91(\mathrm{~m})$ \\
\hline 12 & 125.9 & $5.27(\mathrm{dd} ; J=3.6 ; 3.5 \mathrm{~Hz})$ & 125.0 & $5.18(\mathrm{dd} ; ; J=2.8 ; 5.7 \mathrm{~Hz})$ \\
\hline 13 & 137.9 & & 138.0 & \\
\hline 14 & 42.0 & & 42.0 & \\
\hline 15 & 28.1 & $1.60(\mathrm{~m})$ & 28.0 & $1.60(\mathrm{~m})$ \\
\hline 16 & 25.0 & $1.34(\mathrm{~m})$ & 24.1 & $1.33(\mathrm{~m})$ \\
\hline 17 & 48.1 & & 48.1 & \\
\hline 18 & 53.8 & $2.2(\mathrm{~m})$ & 52.72 & $2.10(\mathrm{~m})$ \\
\hline 19 & 38.5 & $1.00(\mathrm{~m})$ & 38.8 & $1.04(\mathrm{~m})$ \\
\hline 20 & 38.5 & $0.95(\mathrm{~m})$ & 38.8 & $0.98(\mathrm{~m})$ \\
\hline 21 & 30.3 & $1.27(\mathrm{~m})$ & 30.6 & $1.27(\mathrm{~m})$ \\
\hline 22 & 37.4 & $1.72(\mathrm{~m})$ & 37.4 & $1.74(\mathrm{~m})$ \\
\hline 23 & 28.9 & $1.00(\mathrm{~s})$ & 32.9 & $0.94(\mathrm{~s})$ \\
\hline 24 & 15.6 & 0.79 (s) & 15.5 & 0.72 (s) \\
\hline 25 & 15.4 & 0.94 (s) & 15.3 & $0.86(\mathrm{~s})$ \\
\hline 26 & 17.1 & $0.82(\mathrm{~s})$ & 16.9 & 0.94 (s) \\
\hline 27 & 23.5 & $1.10(\mathrm{~s})$ & 23.5 & $0.75(\mathrm{~s})$ \\
\hline 28 & 179.6 & & 180.2 & $1.03(\mathrm{~s})$ \\
\hline 29 & 17.0 & $0.87(\mathrm{dd} ; J=6.4 \mathrm{~Hz})$ & 16.8 & $0.67(\mathrm{~d} ; J=10.0 \mathrm{~Hz})$ \\
\hline 30 & 21.4 & $0.97(\mathrm{dd} ; J=6.3 \mathrm{~Hz})$ & 21.1 & $0.80(\mathrm{~d} ; J=5.5 \mathrm{~Hz})$ \\
\hline
\end{tabular}
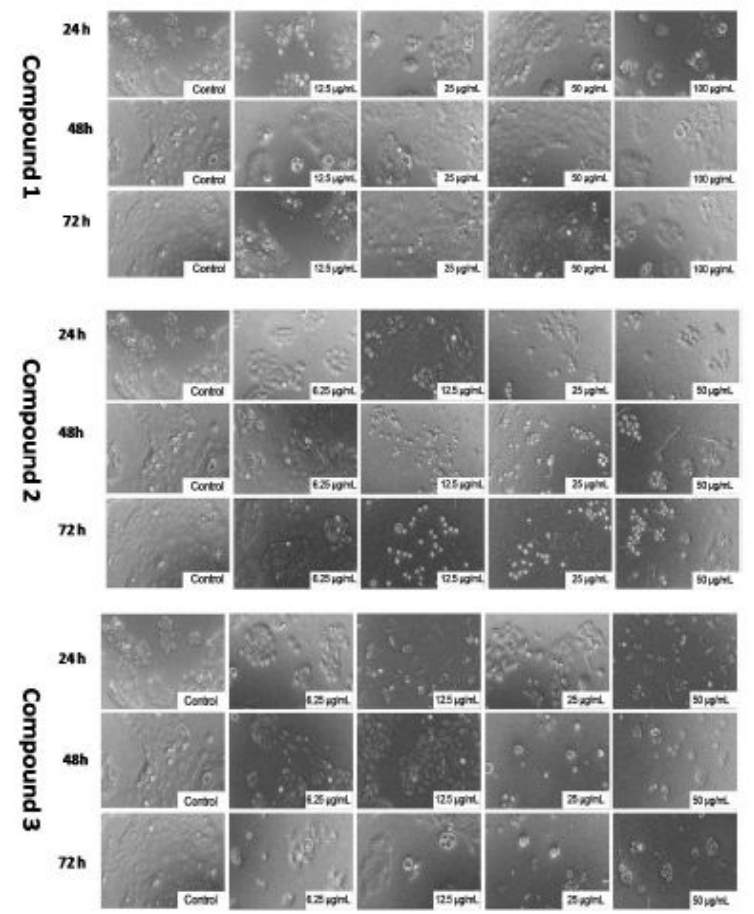

Figure 2: Morphological changes in $\mathrm{NCl}-\mathrm{H} 292$ lung cancer cells after exposure to oleanolic acid (compound 1), ursolic acid (compound 2) and eichlerianic acid (compound 3)

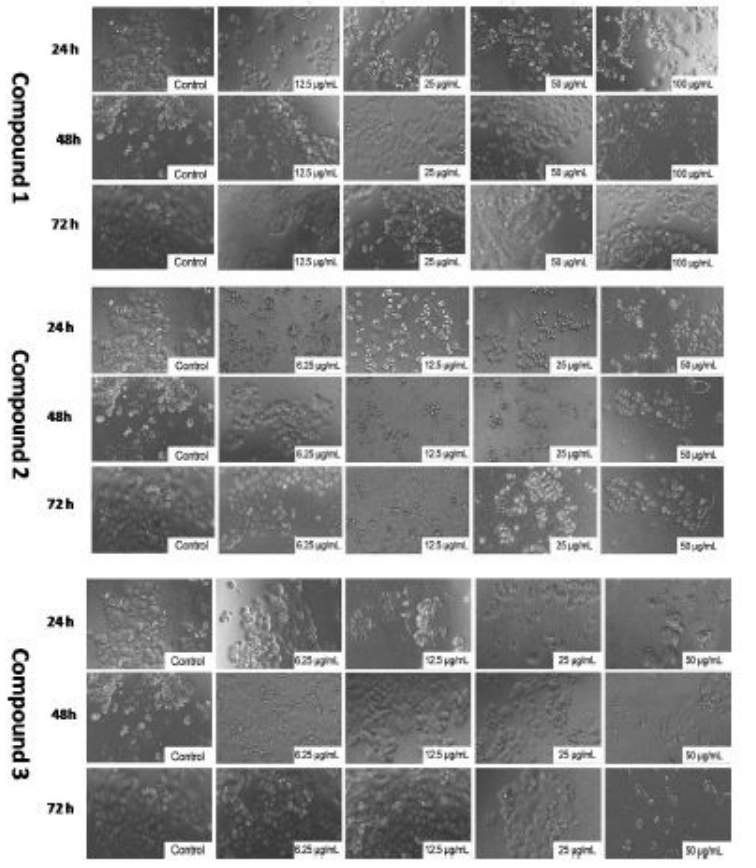

Figure 3: Morphological changes in MCF-7 breast cancer cells after exposure to oleanolic acid (compound 1), ursolic acid (compound 2) and eichlerianic acid (compound $\mathbf{3}$ ) 
Table $3:{ }^{13} \mathrm{C}$ NMR $(150 \mathrm{MHz})$ and ${ }^{1} \mathrm{H}$ NMR data $(600 \mathrm{MHz})$ of compound 3 eichlerianic acid $\left(\mathrm{CDCl}_{3}\right)$

\begin{tabular}{|c|c|c|c|c|}
\hline \multirow[t]{2}{*}{ Position } & \multicolumn{2}{|c|}{ Reported data [14] } & \multicolumn{2}{|c|}{ Observed data } \\
\hline & $\delta \mathrm{C}$ & $\delta \mathrm{H}(\mathrm{J} \mathrm{Hz})$ & $\delta C$ & $\delta$ H (J Hz) \\
\hline \multirow[t]{2}{*}{1} & & $1.75(\mathrm{~m})$ & 34.2 & $1.84(\mathrm{~m})$ \\
\hline & 34.3 & $1.53(\mathrm{~m})$ & & $1.60(\mathrm{~m})$ \\
\hline \multirow[t]{2}{*}{2} & 28.5 & $2.14(\mathrm{~m})$ & 28.1 & 2.18 \\
\hline & & $2.32(\mathrm{~m})$ & & 2.38 \\
\hline 3 & 179.5 & - & 179.0 & - \\
\hline 4 & 147.5 & - & 147.4 & - \\
\hline 5 & 50.8 & - & 49.7 & - \\
\hline 6 & 24.6 & - & 24.6 & - \\
\hline 7 & 33.9 & $1.15(\mathrm{~m})$ & 33.8 & $1.07(\mathrm{~m})$ \\
\hline 8 & 40.0 & - & 40.0 & - \\
\hline 9 & 41.2 & $1.43(\mathrm{~m})$ & 41.1 & $1.48(\mathrm{~m})$ \\
\hline 10 & 39.0 & - & 39.0 & - \\
\hline 11 & 22.3 & $1.35(\mathrm{~m})$ & 22.3 & $1.39(\mathrm{~m})$ \\
\hline 12 & 26.9 & & 26.8 & - \\
\hline 13 & 42.9 & $1.60(\mathrm{~m})$ & 42.8 & $1.65(\mathrm{~m})$ \\
\hline 14 & 50.3 & - & 50.3 & - \\
\hline 15 & 31.4 & $1.40(\mathrm{~m})$ & 31.4 & $1.45(\mathrm{~m})$ \\
\hline 16 & 25.8 & $1.75(\mathrm{~m})$ & 25.8 & $1.75(\mathrm{~m})$ \\
\hline 17 & 49.7 & $1.80(\mathrm{~m})$ & 49.7 & $1.84(\mathrm{~m})$ \\
\hline 18 & 16.3 & $0.82(\mathrm{~s})$ & 16.3 & $0.87 \mathrm{~s}$ \\
\hline 19 & 20.2 & $0.79(\mathrm{~s})$ & 20.2 & $0.84 \mathrm{~s}$ \\
\hline 20 & 86.6 & - & 86.5 & - \\
\hline 21 & 27.1 & $1.08(\mathrm{~s})$ & 27.1 & $1.13 \mathrm{~s}$ \\
\hline 22 & 34.7 & $1.57(\mathrm{~m})$ & 34.7 & $1.60(\mathrm{~m})$ \\
\hline 23 & 26.3 & $1.80(\mathrm{~m})$ & 26.3 & $1.83(\mathrm{~m})$ \\
\hline 24 & 86.3 & $\begin{array}{c}3.57(\mathrm{dd}, J=10.3,5.0 \\
\mathrm{Hz})\end{array}$ & 86.3 & $\begin{array}{l}3.62(\mathrm{dd}, \mathrm{J}= \\
5.5,10.0 \mathrm{~Hz})\end{array}$ \\
\hline 25 & 70.3 & & 70.2 & - \\
\hline 26 & 27.8 & $1.13(\mathrm{~s})$ & 27.8 & $1.17 \mathrm{~s}$ \\
\hline 27 & 23.2 & $1.05(\mathrm{~s})$ & 23.2 & $1.09 \mathrm{~s}$ \\
\hline 28 & & 4.60 (brs) & 113.4 & $4.64 \mathrm{brs}$ \\
\hline & 113.4 & 4.78 (brs) & & $4.83 \mathrm{brs}$ \\
\hline 29 & 24.0 & $1.67(\mathrm{~s})$ & 24.0 & $1.71 \mathrm{~s}$ \\
\hline 30 & 15.3 & $0.99(\mathrm{~s})$ & 15.3 & $0.99 \mathrm{~s}$ \\
\hline
\end{tabular}

what in accordance with the results obtained in the present study. Results of the present study illustrate cytotoxic effects of ursolic acid and eichlerianic acid isolated first time from the leaves of S. hydrophyllacea.

\section{CONCLUSION}

The findings of the present study indicate that ursolic acid and eichlerianic acid isolated from the leaves of $S$. hydrophyllacea grown in Sri Lanka have potentials for the treatment of breast and lung cancer. Detailed molecular studies are necessary to elucidate the anti-cancer mechanisms of these two compounds.

\section{DECLARATIONS}

\section{Acknowledgement}

Financial support provided by International Foundation for Science (IFS), Sweden under grant no. F/5377-1 is gratefully acknowledged. Support provided by Mr. W. A. Sumanadasa, research officer at National Aquatic Resources for the collection of plant materials and support provided by Professor Iqbal Chaudhary, HEJ Research Institute of Chemistry, University of Karachi, for NMR facilities are gratefully acknowledged.

\section{Conflict of interest}

No conflict of interest is associated with this work.

\section{Author contributions}

We declare that this work was done by the authors named in this article and all liabilities pertaining to claims relating to the content of this article will be borne by the authors. Author SRS was involved in designing the study. Authors SRS, MKE, LW, NF, LT and PP were involved in conducting the experiment, AA was involved in structure elucidation of compounds. MKE drafted the manuscript and SRS, MKE, PP and KHT were involved in analyzing data. Manuscript was 
revised by authors SRS, MKE, AA and KHT. All authors read and approved the final manuscript.

\section{REFERENCES}

1. Cohen L, de Moor CA, Eisenberg P, Ming, EE, Hu H. Chemotherapy-induced nausea and vomiting: Incidence and impact on patient quality of life at community oncology settings. Support Care Cancer 2007; 15(5): 497-503.

2. Rogers MP, Blackburn L. Use of neurokinin-1 receptor antagonists in patients receiving moderately or highly emetogenic chemotherapy. Clin J Oncol Nurs 2010; 14: 500-504.

3. Bloechl-Daum B, Deuson RR, Mavros $P$, Hansen $M$, Herrstedt J. Delayed nausea and vomiting continue to reduce patients' quality of life after highly and moderately emetogenic chemotherapy despite antiemetic treatment. J Clin Oncol 2006; 24(27): 44724478.

4. Grunberg SM, Deuson RR, Mavros P, Geling O, Hansen M, Cruciani G, Daniele B, De Pouvourville G, Rubenstein EB, Daugaard $G$. Incidence of chemotherapy-induced nausea and emesis after modern anti-emetics. Cancer 2004; 100(10): $2261-$ 2268

5. Ihbe-Heffinger A, Ehlken, B, Bernard, R, Berger, $K$, Peschel C, Eichler HG, Deuson R, Thödtmann1 J, Lordick $F$. The impact of delayed chemotherapy-induced nausea and vomiting on patients, health resource utilization and costs in German cancer centers. Ann Oncol 2004; 15(3): 526-536.

6. Stewart DJ. Mechanisms of resistance to cisplatin and carboplatin. Crit Rev Oncol Hematol 2007; 63(1): 12- 31.

7. Newman DJ, Cragg GM, Snader KM. Natural products as sources of new drugs over the period 1981-2002. J Nat Prod 2003; 66(7): 1022-1037.

8. Lima AA, Parial R, Das M, Kumar AD. Phytochemical and pharmacological studies of ethanolic extract from the leaf of Mangrove plant Phoenix paludosa Roxb. Malays J Pharmaceut Sci 2010; 8(2): 59-69

9. Tao SH, Wu J, Qi SH, Zhang S, Li MY, Li QX. Scyphiphorins $A$ and $B$, two new iridoid glycosides from the stem bark of a Chinese mangrove Scyphiphora hydrophyllacea. Helv Chim Acta 2007; 90(9): 17181722.

10. Samarakoon $S R$, Shanmuganathan $C$, Ediriweera $M K$, Piyathilaka P, Tennekoon KH, Thabrew I, Galhena P, De Silva ED. Anti-hepatocarcinogenic and anti-oxidant effects of mangrove plant Scyphiphora hydrophyllacea. Pharmacogn Mag. 2017; 13(Supp/ 1): S76.
11. Samarakoon SR, Fernando N, Ediriweera MK, Adhikari A, Wijayabandara L, de Silva ED, Tennekoon $\mathrm{KH}$. Isolation of Hopenone-l from the Leaves of Mangrove Plant Scyphiphora hydrophyllacea and Its Cytotoxic Properties. Br J Pharm Res 2016; 10: 1-6.

12. Samarakoon $S R$, Thabrew I, Galhena $P B$, De Silva $D$, Tennekoon KH. A comparison of the cytotoxic potential of standardized aqueous and ethanolic extracts of a polyherbal mixture comprised of Nigella sativa (seeds), Hemidesmus indicus (roots) and Smilax glabra (rhizome). Pharmacog Res 2010; 2: 335-342.

13. Ediriweera MK, Tennekoon KH, Samarakoon $S R$, Thabrew I, de Silva ED. Protective Effects of six selected dietary compounds against leptin-induced proliferation of oestrogen receptor positive (MCF-7) breast cancer cells. Medicines 2017; 4(3): 56.

14. Kamarulzaman FA, Mohamad K, Awang K, Lee HB. Chemical Constituents of Aglaia lanuginose. Pertanika $J$ SciTechnol 2014; 22(1): 82-86.

15. Martins D, Carrion LL, Ramos DF, Salomé KS, da Silva $P E$, Barison A, Nunez CV. Triterpenes and the antimycobacterial activity of Duroiamacrophylla Huber (Rubiaceae). BioMed Res Int 2013; Article ID 605831.

16. Ghosh A, Misra S, Dutta AK, Choudhury A. Pentacyclic triterpenoids and sterols from seven species of mangrove. Phytochemistry 1985; 24(8): 1725-1727.

17. Misra S, Choudhury A, Chattopadhyay S, Ghosh A. Lipid composition of Porteresia coarctata from two different mangrove habitats in India. Phytochemistry 1988; 27(2): 361-364.

18. Truong NB, Pham CV, Doan HT, Nguyen HV, Nguyen $C M$, Nguyen HT, Zhang HJ, Fong HH, Franzblau SG, Soejarto DD, Chau MV. Anti-tuberculosis cycloartane triterpenoids from Radermachera boniana. J Nat Prod 2011; 74(5): 1318-1322.

19. Yan HJ, Wang JS, Kong LY. Cytotoxic dammarane-type triterpenoids from the stem bark of Dysoxylum binecteriferum. J Nat Prod 2014; 77(2): 234-242.

20. Frighetto RT, Welendorf RM, Nigro EN, Frighetto $N$, Siani AC. Isolation of ursolic acid from apple peels by high speed counter-current chromatography. Food Chem 2008; 106(2): 767-771

21. Saraswat B, Visen P, Agarwal DP. Ursolic acid isolated from Eucalyptus tereticornis protects against ethanol toxicity in isolated rat hepatocytes. Phytother Res 2000; 14(3): 163-166.

22. Es-Saady D, Simon A, Jayat-Vignoles C, Chulia AJ, Delage C. MCF-7 cell cycle arrested at G1 through ursolic acid, and increased reduction of tetrazolium salts. Anticancer Res 1996; 16(1): 481-486.

23. Liu $B, X u$ YK. Cytotoxicity and synergistic effect of the constituents from roots of Aglaia odorata (Meliaceae). Nat Prod Res 2016; 30(4): 433-437. 